\title{
Milliliter per Mole per Second
}

National Cancer Institute

\section{Source}

National Cancer Institute. Milliliter per Mole per Second. NCI Thesaurus. Code C85719.

Milliliters per mole per second. 